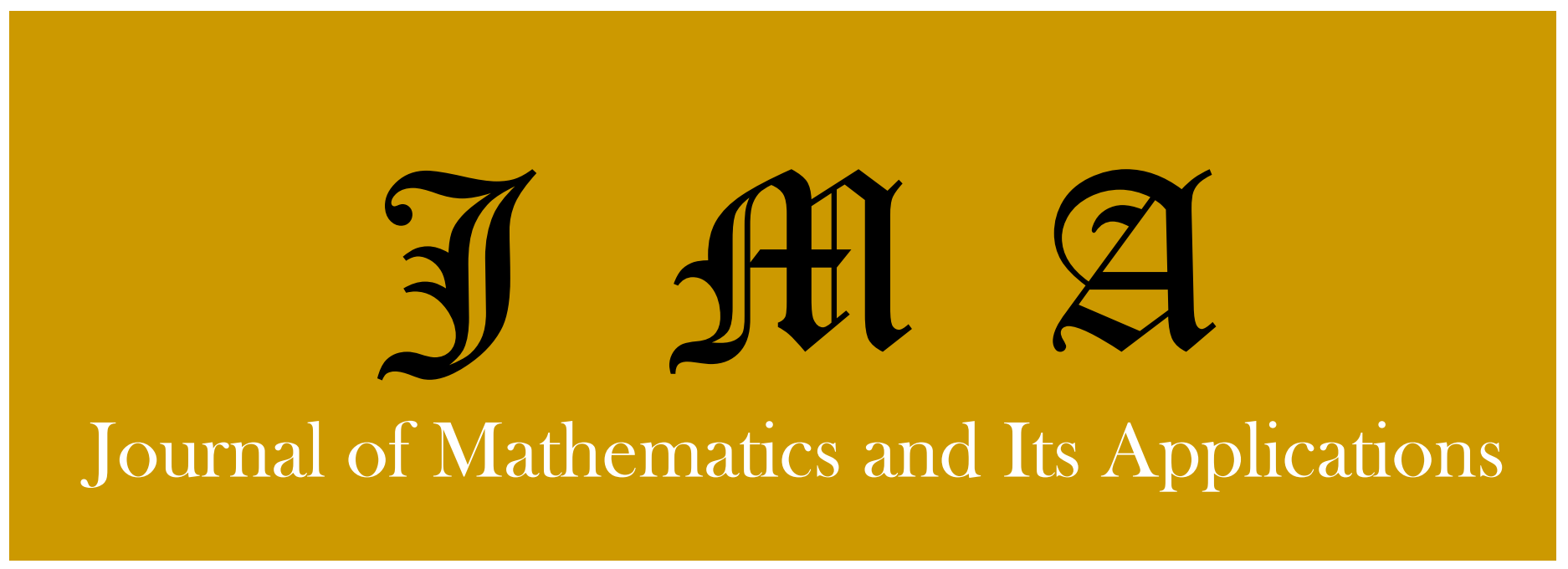

Volume 14, No. 2

\section{December 2015}

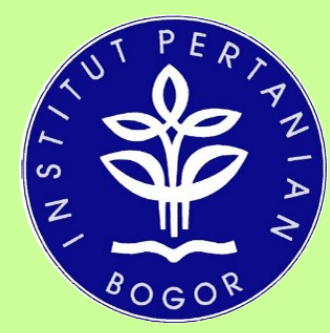

Department of Mathematics FMIPA - Institut Pertanian Bogor

JIn. Meranti, Kampus IPB Dramaga - Bogor

Phone/Fax: (0251) 8625276

E-mail: math@ipb.ac.id

jma.mathipb@gmail.com
Aplikasi Metode Transformasi Diferensial pada Sistem Persamaan Diferensial Biasa

E. Khatizah, P. T. Karima, dan D. I. Astuti

Penyelesaian Masalah Syarat Batas Persamaan Diferensial Biasa dalam Software $R$ dengan Menggunakan Bvpsolve W. Erliana, A. D. Garnadi, S. Nurdiati, dan M. T. Julianto

Pemodelan Frekuensi Petir di Bogor Menggunakan Pendekatan Logika Fuzzy

S. Nurdiati, E. Khatizah, dan N. Rosdiyana

Model Stokastik Penyebaran Penyakit Demam Berdarah di Kota Depok

H. Sumarno, P. Sianturi, A. Kusnanto, dan Siswadi

Penjadwalan Kegiatan Perkuliahan Menggunakan Goal Programming: Studi Kasus di Program Studi S1 Matematika FMIPA IPB

Ruhiyat, F. Hanum, dan R. A. Permana

Pemanfaatan Sumber Daya Alam Terbarukan dalam Model Sewa Ekonomi

F. Hanum, E. H. Nugrahani, dan S. Susanti 


\title{
PEMODELAN FREKUENSI PETIR DI BOGOR MENGGUNAKAN PENDEKATAN LOGIKA FUZZY
}

\author{
S. NURDIATI ${ }^{1}$, E. KHATIZAH ${ }^{1}$, N. ROSDIYANA ${ }^{2}$
}

\begin{abstract}
Abstrak
Guinness Book of Record pada tahun 1989 dalam artikel Antara News (2013) menunjukkan bahwa Bogor adalah salah satu daerah yang memiliki potensi petir tertinggi di dunia. Namun, alat pencatat frekuensi petir yaitu lightning counter sering mengalami kerusakan sehingga data frekuensi petir tidak tercatat dengan baik. Penelitian ini dilakukan untuk membuat model frekuensi petir di Bogor menggunakan pendekatan logika fuzzy. Metode yang digunakan adalah metode Mamdani yang terdiri atas empat tahapan yaitu fuzzifikasi, aplikasi fungsi implikasi, agregasi semua aturan, dan defuzzifikasi. Model yang terbentuk mengambil input berupa suhu udara, kelembaban udara, kecepatan angin, curah hujan dan penguapan. Output dari model ini adalah frekuensi petir. Hasil penelitian menunjukkan bahwa terdapat 81 aturan model frekuensi petir. Keakuratan pemodelan fuzzy dapat dilihat dari nilai mean percentage absolute error (MAPE) sebesar 17.2\%.
\end{abstract}

Kata kunci: petir, pemodelan fuzzy, MAPE

\section{PENDAHULUAN}

Bogor merupakan salah satu daerah yang berpotensi rawan petir karena memiliki topografi yang memungkinkan tumbuhnya awan-awan konvektif di sekitar lereng pegunungan. Sejumlah pegunungan yang mengelilingi Bogor dengan ketinggian mencapai ribuan kaki dapat mengalihkan awan menuju ketinggian yang potensial menimbulkan terjadinya petir [12]. Daerah yang dikenal dengan julukan kota hujan ini memiliki curah hujan yang sangat tinggi sehingga berpotensi menghasilkan petir dengan frekuensi yang besar. Petir merupakan pelepasan muatan elektrostatis yang berasal dari badai guntur [5]. Artikel Antara News (2013) menyebutkan bahwa Bogor adalah salah satu daerah yang memiliki potensi petir sangat tinggi di dunia, tercatat dalam Guinness Book of Record pada tahun 1989.

Keberadaan petir memberikan beberapa manfaat antara lain sebagai sumber energi, pemicu terjadinya reaksi kimia dalam pembentukan lapisan ozon, dan pembentukan NH4 untuk kesuburan tanah. Namun, serangan petir dapat menjadi bencana. Serangan petir dapat mengganggu transmisi listrik, menimbulkan tegangan tinggi, dan merenggut nyawa manusia yang terkena serangan secara langsung. Bahaya yang ditimbulkan dari sambaran petir ini sangat merugikan manusia sehingga kita perlu waspada dan hati-hati pada saat hujan yang disertai petir [6].

Badan Meteorologi Klimatologi dan Geofisika (BMKG) memiliki peranan

${ }^{1}$ Departemen Matematika, Fakultas Ilmu Matematika dan Pengetahuan Alam, Jalan Meranti Kampus IPB Dramaga Bogor, 16680.

${ }^{2}$ Mahasiswa S1, Departemen Matematika, Fakultas Ilmu Matematika dan Pengetahuan Alam, Jalan Meranti Kampus IPB Dramaga Bogor, 16680. 
penting dalam mengamati gejala petir di Indonesia. Menurut peneliti Jepang Suichi Mori dalam artikel Antara News (2013), data mengenai petir dapat digunakan untuk memprediksi cuaca secara akurat. Selain itu, data hasil penelitian petir dapat dimanfaatkan untuk mengurangi dampak petir terhadap instalasi-instalasi petir. Bogor memiliki pencatat frekuensi petir yang terletak di Stasiun Klimatologi Kelas satu BMKG Dramaga, Bogor. Salah satu alat yang digunakan dalam BMKG adalah lightning counter. Lightning counter merupakan alat pencatat frekuensi petir dalam radius $\pm 10 \mathrm{~km}$ dari sumber pengamatan. Namun, keterbatasan sarana dalam pemeliharaan dan perawatan mengakibatkan seringnya terjadi kerusakan pada lightning counter. Salah satu kendala dalam memperbaiki alat tersebut adalah harus mendatangkan seorang teknisi dari kantor pusat yang tidak bisa dilakukan sembarang waktu. Hal ini yang menyebabkan data frekuensi petir kurang tercatat dengan baik. Kondisi alat pencatat frekuensi petir yang rusak dapat menyulitkan para ahli dalam mengamati dan menghasilkan prediksi data frekuensi petir.

Oleh karena itu, diperlukan suatu model yang dapat membantu para ahli dalam memprediksi sambaran petir. Salah satu cara yang dapat dilakukan adalah membuat model yang menghubungkan antara faktor-faktor yang memengaruhi terjadinya sambaran petir. Pemodelan frekuensi petir ini menggunakan pendekatan logika fuzzy yang mengadopsi pengetahuan manusia ke komputer dan dapat menyelesaikan masalah seperti yang dilakukan para ahli. Diharapkan dengan pendekatan ini pengambilan keputusan dapat dilakukan secara tepat mendekati hasil pengetahuan para ahli.

\section{PEMODELAN FUZZY}

Pendekatan logika fuzzy yang digunakan pada penelitian ini adalah metode Mamdani. Metode Mamdani atau dikenal dengan metode maximum-minimum yang dapat menerima masukan dari manusia, intuitif, dan berdasarkan penalaran manusia [7]. Ebrahim Mamdani memperkenalkan metode tersebut pada tahun 1975. Tahapan mendapatkan output, yaitu:

\section{1) Pembentukan himpunan fuzzy}

Fuzzifikasi merupakan proses mengubah variabel tegas menjadi variabel fuzzy [4]. Variabel ditentukan berdasarkan proses yang akan dilakukan. Himpunan fuzzy pada metode Mamdani dibagi menjadi satu atau lebih himpunan. Fungsi keanggotaan adalah suatu bentuk untuk mencari nilai keanggotaan. Nilai keanggotaan pada himpunan fuzzy terletak pada rentang 0 sampai 1 . Nilai keanggotaan diperlukan untuk memberikan bobot pada suatu variabel, sehingga variabel tersebut dapat dinyatakan dengan nilai. 


\section{2) Aplikasi fungsi implikasi}

Penyusunan basis aturan berupa implikasi fuzzy yang menyatakan relasi antara variabel input dan output. Fungsi implikasi yang digunakan dalam metode Mamdani adalah min dengan operator and pada setiap aturan. Metode ini mengambil nilai keanggotaan terkecil antarelemen pada himpunan yang sesuai. Persamaan dari setiap aturan dalam fungsi implikasi, yaitu:

$$
\text { IF }\left(x_{1} \text { is } A_{1}\right) \text { and }\left(x_{2} \text { is } A_{2}\right) \text { THEN } y \text { is } B
$$

dengan A dan B adalah himpunan fuzzy, sedangkan $x$ dan $y$ merupakan variabel fuzzy. Proposisi yang mengikuti IF disebut anteseden, sedangkan proposisi yang mengikuti THEN disebut konsekuen [7].

\section{3) Agregasi semua aturan}

Agregasi semua aturan menggunakan metode max. Solusi himpunan fuzzy dapat diperoleh dengan cara mengambil nilai maksimum aturan, kemudian menggunakannya untuk memodifikasi daerah fuzzy, dan mengaplikasikannya ke output dengan menggunakan operator or. Secara umum dituliskan:

$$
\mu_{s f}\left(x_{i}\right)=\max \left(\mu_{s f}\left(x_{i}\right), \mu_{k f}\left(x_{i}\right)\right)
$$

dengan $\mu_{s f}\left(x_{i}\right)$ adalah nilai keanggotaan solusi fuzzy sampai aturan ke-i dan $\mu_{k f}\left(x_{i}\right)$ adalah nilai keanggotaan konsekuen fuzzy aturan ke-i [7].

\section{4) Defuzzifikasi}

Defuzzifikasi adalah proses pengubahan output fuzzy ke output crisp [9]. Input dari proses defuzzifikasi adalah suatu himpunan fuzzy yang diperoleh dari agregasi semua aturan fuzzy, sedangkan output yang dihasilkan berupa bilangan pada domain himpunan fuzzy tersebut [7]. Proses defuzzifikasi menggunakan metode centroid (composite moment) dengan output diperoleh mengambil titik pusat daerah fuzzy. Secara umum dituliskan:

$$
z^{*}=\left\{\begin{array}{l}
\frac{\int_{z} z \mu(z) d z}{\int_{z} \mu(z) d z} ; \text { untuk variabel kontinu } \\
\frac{\sum_{j=1}^{n} z_{j} \mu\left(z_{j}\right)}{\sum_{j=1}^{n} \mu\left(z_{j}\right)} ; \text { untuk variabel diskret }
\end{array}\right.
$$

dengan $\mathrm{z}^{*}$ adalah titik pusat, $\mathrm{z}$ adalah domain himpunan fuzzy, dan $\mu$ adalah derajat keanggotan. 


\section{HASIL PEMODELAN FUZZY}

Data yang digunakan adalah data frekuensi petir dan data iklim hasil pengamatan tahun 2012 di Stasiun Klimatologi Kelas satu BMKG Dramaga, Bogor. Varibel input berupa faktor-faktor terjadinya petir yang dibatasi sampai data iklim saja seperti: suhu udara rata-rata, penguapan, kelembaban udara, kecepatan angin, penguapan, curah hujan, dan variabel output berupa frekuensi petir.

\section{1) Pembentukan Himpunan Fuzzy}

\section{Suhu Udara Rata-Rata}

Data tegas dari suhu udara rata-rata dibuat histogram sehingga dapat terlihat trend datanya. Kemudian mengubah nilai tegas suhu udara rata-rata menjadi nilai samar berdasarkan histogramnya. Suhu udara rata-rata (T) memiliki fungsi keanggotaan dengan bentuk trapesium sebagai berikut:

$$
\begin{gathered}
\mu_{\mathrm{T} \mathrm{SRe}}(x)=\left\{\begin{array}{rl}
0, & x \geq 25.1 \\
1, & x \leq 24.2 \\
\frac{25.1-x}{0.9}, & 24.2 \leq x \leq 25.1
\end{array} \quad \mu_{\mathrm{T} \mathrm{S}}(x)=\left\{\begin{aligned}
0, & x \leq 26.2 \text { atau } x \geq 26.9 \\
\frac{x-26.2}{0.2}, & 26.2 \leq x \leq 26.4 \\
1, & 26.4 \leq x \leq 26.6
\end{aligned}\right.\right. \\
\mu_{\mathrm{T} \mathrm{Re}}(x)=\left\{\begin{array}{rl}
\frac{x-24.4}{0.3}, & x \leq 24.4 \text { atau } x \geq 25.5 \\
0.7, & 24.4 \leq x \leq 25.1 \\
1, & 25.1 \leq x \leq 25.2 \\
\frac{25.5-x}{0.3}, & 25.2 \leq x \leq 25.5
\end{array} \quad \mu_{\mathrm{T} \mathrm{T}}(x)=\left\{\begin{array}{rl}
0.26 .7 & x \leq 26.7 \\
0.2 & 26.7 \leq x \leq 26.9 \\
1, & x \geq 26.9
\end{array}\right.\right. \\
\mu_{\mathrm{T} \mathrm{N}}(x)=\left\{\begin{aligned}
\frac{x-25.2}{0.3}, & 25.2 \leq x \leq 25.5 \\
1, & 25.5 \leq x \leq 26 \\
\frac{26.4-x}{0.4}, & 26 \leq x \leq 26.4
\end{aligned}\right.
\end{gathered}
$$

Representasi untuk variabel suhu udara diperlihatkan pada Gambar 1.

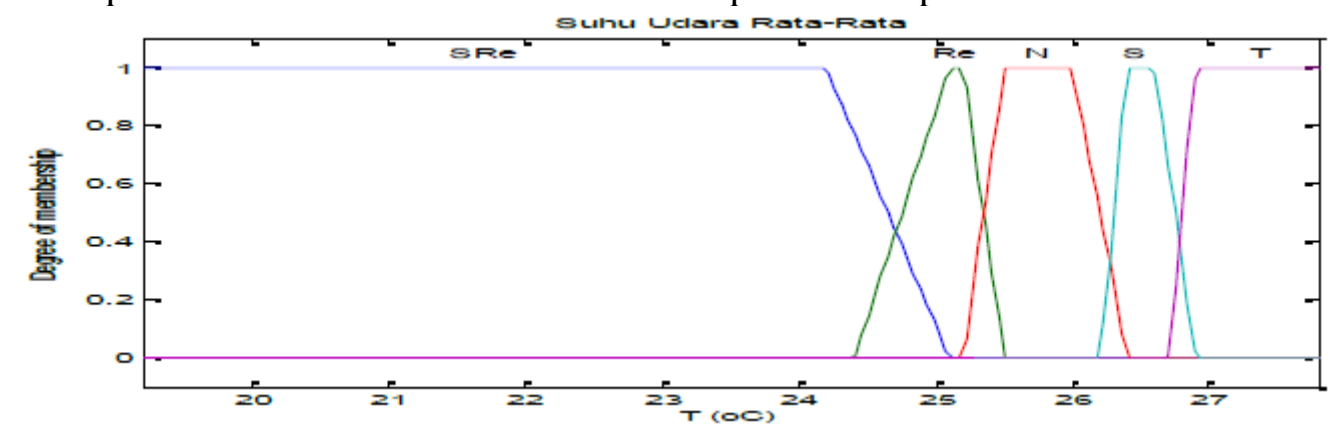

Gambar 1 Representasi Variabel Suhu Udara Rata-Rata di Bogor tahun 2012 


\section{Kelembaban Udara}

Data tegas dari kelembaban udara dilihat juga tren-nya melalui histogram dan kemudian diubah menjadi nilai samar. Jika $x$ menyatakan kelembaban udara, maka kelembaban udara $(\mathrm{RH})$ memiliki fungsi keanggotaan dengan bentuk trapesium sebagai berikut:

$$
\begin{gathered}
\mu_{\mathrm{RH} e}(x)=\left\{\begin{array}{rl}
0, & x \geq 83 \\
1, & x \leq 79 \\
\frac{83-x}{4}, & 79 \leq x \leq 83
\end{array} \quad \mu_{\mathrm{RHT}}(x)=\left\{\begin{aligned}
0, & x \leq 91 \\
\frac{x-91}{3,} & 91 \leq x \leq 94 \\
1, & x \geq 94
\end{aligned}\right.\right. \\
\mu_{\mathrm{RH} S}(x)=\left\{\begin{array}{cl}
0, & x \leq 81 \text { atau } x \geq 94 \\
\frac{x-81}{2}, & 81 \leq x \leq 83 \\
1, & 83 \leq x \leq 89 \\
\frac{94-x}{5}, & 89 \leq x \leq 94
\end{array}\right.
\end{gathered}
$$

Representasi variabel kelembaban udara diperlihatkan pada Gambar 2.

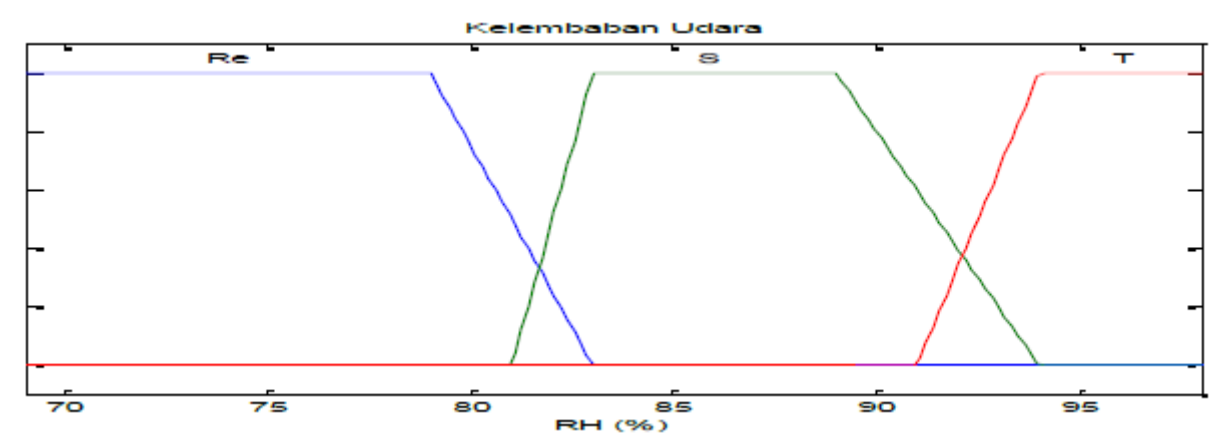

Gambar 2 Representasi Kelembaban Udara di Bogor Tahun 2012

\section{Kecepatan Angin}

Fungsi keanggotaan untuk kecepatan angin adalah sebagai berikut:

$$
\begin{gathered}
\mu_{\mathrm{ASL}}(x)=\left\{\begin{array}{rl}
0, & x \geq 3.1 \\
1, & x \leq 2.8 \\
\frac{3.1-x}{0.3}, & 2.8 \leq x \leq 3.1
\end{array} \quad \mu_{\mathrm{AK}}(x)=\left\{\begin{aligned}
\frac{x-4.2}{0.2}, & 4.2 \leq x \leq 4.4 \\
1, & 4.4 \leq x \leq 4.7 \\
\frac{5.2-x}{0.5}, & 4.7 \leq x \leq 5.2
\end{aligned}\right.\right. \\
\mu_{\mathrm{AL}}(x)=\left\{\begin{aligned}
\frac{x-2.9}{0.2}, & 2.9 \leq x \leq 3.1 \\
1, & 3.1 \leq x \leq 3.7 \\
\frac{3.9-x}{0.2}, & 3.7 \leq x \leq 3.9 \\
0, & x \leq 3.8 \text { atau } x \geq 4.4
\end{aligned}\right. \\
\mu_{\mathrm{AS}}(x)=\left\{\begin{aligned}
0, & x \leq 4.9 \\
\frac{x-3.8}{0.1}, & 3.8 \leq x \leq 3.9 \\
1, & 3.9 \leq x \leq 4.2 \\
\frac{4.4-x}{0.2}, & 4.2 \leq x \leq 4.4
\end{aligned}\right.
\end{gathered}
$$




$$
\mu_{\mathrm{pT}}(x)=\left\{\begin{array}{rl}
0, & x \leq 5.2 \text { atau } x \geq 6.7 \\
\frac{x-5.2}{0.1}, & 5.2 \leq x \leq 5.3 \\
1, & 5.3 \leq x \leq 5.8 \\
\frac{6.7-x}{0.9}, & 5.8 \leq x \leq 6.7
\end{array} \quad \mu_{\mathrm{p} \mathrm{ST}}(x)=\left\{\begin{aligned}
0, & x \leq 5.9 \\
1, & x \leq 6.7 \\
\frac{x-5.9}{0.8}, & 5.9 \leq x \leq 6.7
\end{aligned}\right.\right.
$$

Representasi variabel kecepatan angin diperlihatkan pada Gambar 3.

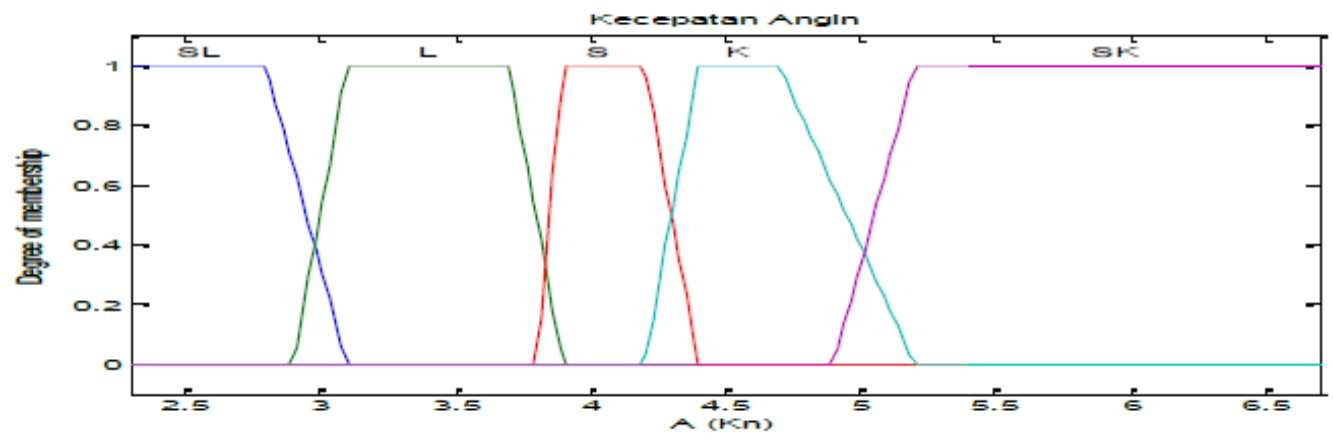

Gambar 3 Representasi Kecepatan Angin di Bogor Tahun 2012

\section{Penguapan}

Fungsi keanggotaan untuk variabel penguapan adalah sebagai berikut:

$$
\begin{aligned}
& \mu_{\mathrm{PSRe}}(x)=\left\{\begin{aligned}
0, & x \geq 3.3 \\
1, & x \leq 2.6 \\
\frac{3.3-x}{0.7}, & 2.6 \leq x \leq 3.3
\end{aligned}\right. \\
& \mu_{\mathrm{PARe}}(x)=\left\{\begin{array}{cl}
0, & x \leq 3.2 \text { atau } x \geq 4.2 \\
\frac{x-3.2}{0.1}, & 3.2 \leq x \leq 3.3 \\
1, & 3.3 \leq x \leq 3.7 \\
\frac{4.2-x}{0.5}, & 3.7 \leq x \leq 4.2
\end{array}\right. \\
& \mu_{\mathrm{PRe}}(x)=\left\{\begin{array}{rl}
0, & x \leq 3.9 \text { atau } x \geq 4.6 \\
\frac{x-3.9}{0.3}, & 3.9 \leq x \leq 4.2 \\
1, & 4.2 \leq x \leq 4.3 \\
\frac{4.6-x}{0.3}, & 4.3 \leq x \leq 4.6
\end{array} \quad \mu_{\mathrm{P} \mathrm{ST}}(x)=\left\{\begin{aligned}
0, & x \leq 5.9 \\
1, & x \leq 6.7 \\
\frac{x-5.9}{0.8}, & 5.9 \leq x \leq 6.7
\end{aligned}\right.\right. \\
& \mu_{\mathrm{ps}}(x)=\left\{\begin{aligned}
0, & x \leq 4.3 \text { atau } x \geq 4.9 \\
\frac{x-4.3}{0.3}, & 4.3 \leq x \leq 4.6 \\
1, & 4.6 \leq x \leq 4.7 \\
\frac{4.9-x}{0.2}, & 4.7 \leq x \leq 4.9
\end{aligned}\right. \\
& \mu_{\mathrm{PAT}}(x)=\left\{\begin{aligned}
0, & x \leq 4.7 \text { atau } x \geq 5.3 \\
\frac{x-4.7}{0.2}, & 4.7 \leq x \leq 4.9 \\
1, & 4.9 \leq x \leq 5 \\
\frac{5.3-x}{0.3}, & 5 \leq x \leq 5.3
\end{aligned}\right. \\
& \mu_{\mathrm{p} \mathrm{T}}(x)=\left\{\begin{aligned}
0, & x \leq 5.2 \text { atau } x \geq 6.7 \\
\frac{x-5.2}{0.1}, & 5.2 \leq x \leq 5.3 \\
1, & 5.3 \leq x \leq 5.8 \\
\frac{6.7-x}{0.9}, & 5.8 \leq x \leq 6.7
\end{aligned}\right.
\end{aligned}
$$


Representasi variabel penguapan diperlihatkan pada Gambar 4.

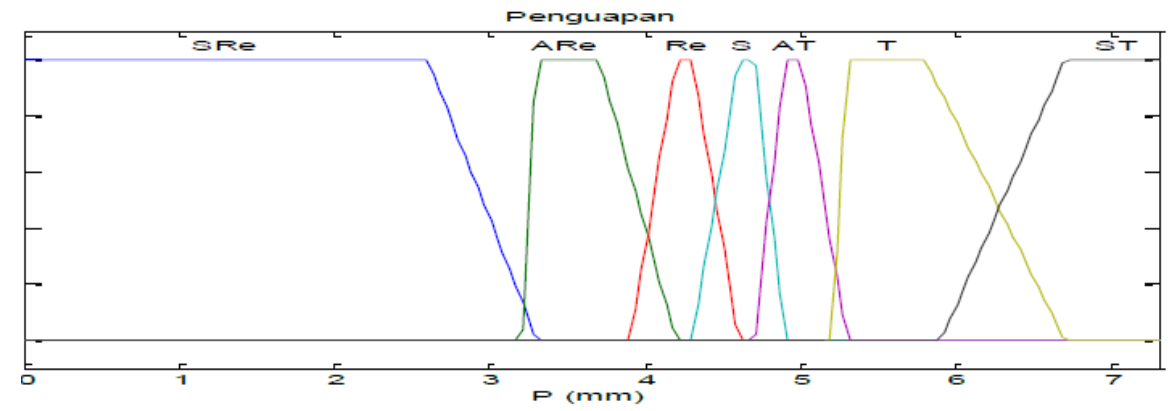

Gambar 4 Representasi Penguapan di Bogor Tahun 2012

\section{Curah Hujan}

Jika $x$ menyatakan curah hujan, maka fungsi keanggotaan curah hujan yang memiliki bentuk trapesium yaitu sebagai berikut:

$$
\begin{gathered}
\mu_{\mathrm{CH} \mathrm{SRi}}(x)=\left\{\begin{array}{cl}
0, & x \geq 1 \\
1, & x \leq 0.4 \\
\frac{1-x}{0.6}, & 0.4 \leq x \leq 1
\end{array} \quad \mu_{\mathrm{CH} \mathrm{S}}(x)=\left\{\begin{array}{cl}
0, & x \leq 7.1 \text { atau } x \geq 34.5 \\
\frac{x-7.1}{2.5}, & 7.1 \leq x \leq 9.6 \\
1, & 9.6 \leq x \leq 22.2
\end{array}\right.\right. \\
\mu_{\mathrm{CH} \mathrm{Ri}}(x)=\left\{\begin{array}{cll}
\frac{34.5-x}{12.3}, & 22.2 \leq x \leq 34.5 \\
\frac{x-0.4}{0.6}, & 0.4 \leq x \leq 1 \\
1, & 1 \leq x \leq 7.1 \\
\frac{9.6-x}{2.5}, & 7.1 \leq x \leq 9.6
\end{array} \quad \mu_{\mathrm{CH} \mathrm{Le}}(x)=\left\{\begin{array}{cl}
0, & x \leq 22.2 \\
1, & x \geq 34.5 \\
\frac{x-22.2}{12.3}, & 22.2 \leq x \leq 34.5
\end{array}\right.\right.
\end{gathered}
$$

Representasi variabel curah hujan diperlihatkan pada Gambar 5.

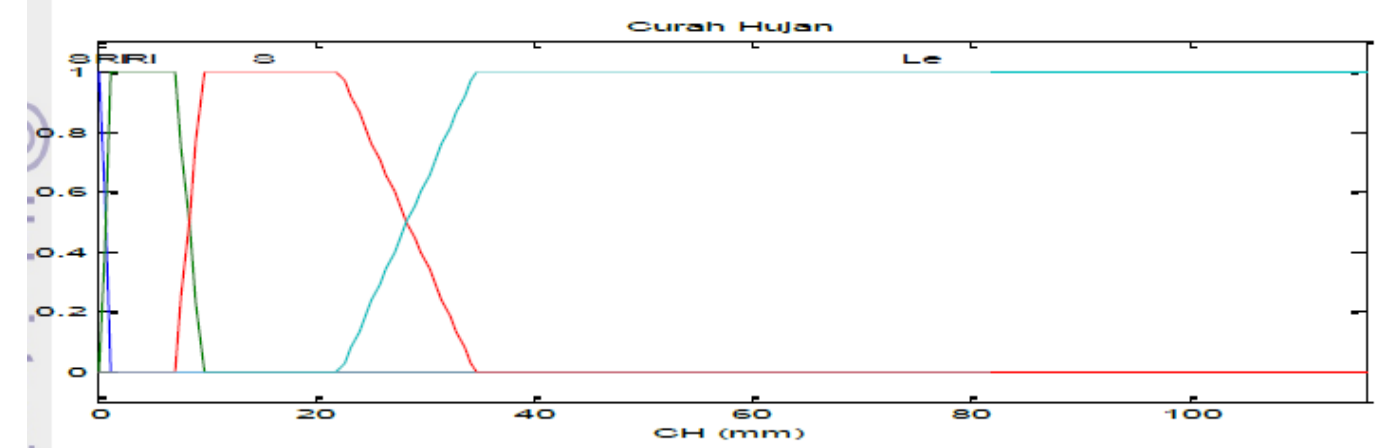

Gambar 5 Representasi Curah Hujan di Bogor Tahun 2012

\section{Frekuensi Petir}

Variabel input berupa frekuensi petir. Representasi variabel frekuensi petir diperlihatkan pada Gambar 6. 


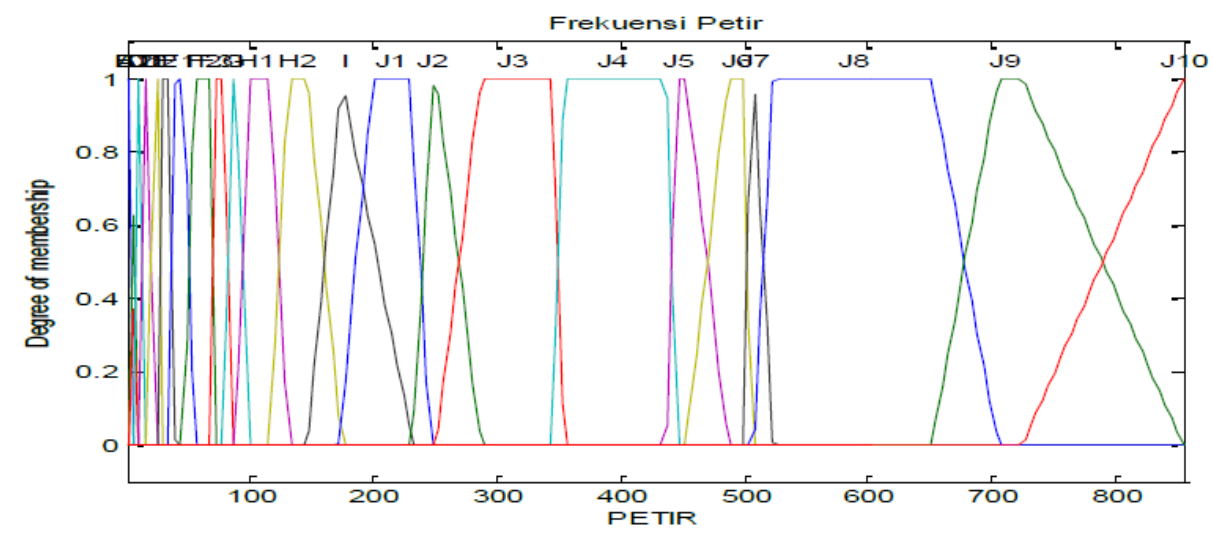

Gambar 6 Representasi Frekuensi Petir di Bogor Tahun 2012

\section{2) Aplikasi Fungsi Implikasi}

Pada metode fuzzy Mamdani fungsi implikasi yang digunakan adalah metode min dengan operator fuzzy and, oleh karena metode min yang digunakan maka input terkecil yang akan diambil. Misalkan contoh aturan yang dapat menyatakan relasi antara variabel input dengan variabel output adalah sebagai berikut:

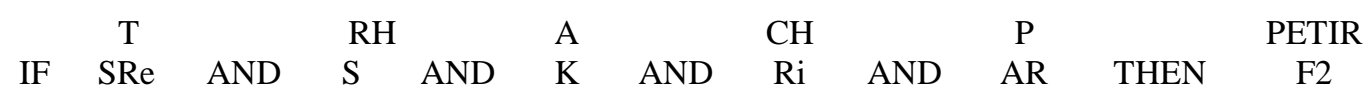

Jika T (suhu udara) Sangat Rendah dan RH (kelembaban udara) Sedang dan A (kecepatan angin) Kuat dan $\mathrm{CH}$ (curah hujan) Ringan dan $\mathrm{P}$ (penguapan) Agak Rendah, maka PETIR F2 dengan frekuensi petir antara 55 sampai 70.

$$
\begin{aligned}
\alpha{\text { - } \text { predikat }_{1}} & =\mu_{T S R e} \cap \mu_{R H S} \cap \mu_{A K} \cap \mu_{C H S R i} \cap \mu_{P A R} \\
& =\min \left(\mu_{T S R e}(25.2), \mu_{R H S}(84), \mu_{A K}(3.9), \mu_{C H S R}(26.3), \mu_{P A R}(7.3)\right) \\
& =\min (0 ; 1 ; 0 ; 0 ; 0)=0
\end{aligned}
$$

\section{3) Agregasi Semua Aturan}

Agregasi semua aturan menggunakan metode max dengan operator fuzzy or. Dengan demikian, solusi himpunan fuzzy diperoleh dengan cara mengambil nilai maksimum aturan. Setelah itu, output didapatkan dengan cara defuzzifikasi. Gambar 7 menunjukkan proses agregasi semua aturan.

\section{4) Defuzzifikasi}

Hasil agregasi semua aturan berupa himpunan fuzzy, oleh karena itu perlu dilakukan proses defuzzifikasi untuk memperoleh nilai berupa anggota himpunan crisp (tegas). Metode yang digunakan pada kasus ini adalah metode centroid, yaitu dengan mengambil titik pusat himpunan fuzzy tersebut (Gambar 8). Dengan demikian dihasilkan bila $\mathrm{T}$ (suhu udara) sebesar $25.2^{\circ} \mathrm{Cdan} \mathrm{RH}$ (kelembaban udara) sebesar $84 \%$ dan A (kecepatan angin) sebesar $3.9 \mathrm{kn}$ dan $\mathrm{CH}$ (curah hujan) sebear $26.3 \mathrm{~mm}$ dan $\mathrm{P}$ (penguapan) sebesar $7.3 \mathrm{~mm}$, maka diperoleh prediksi frekuensi petir yang terjadi adalah 75 . 


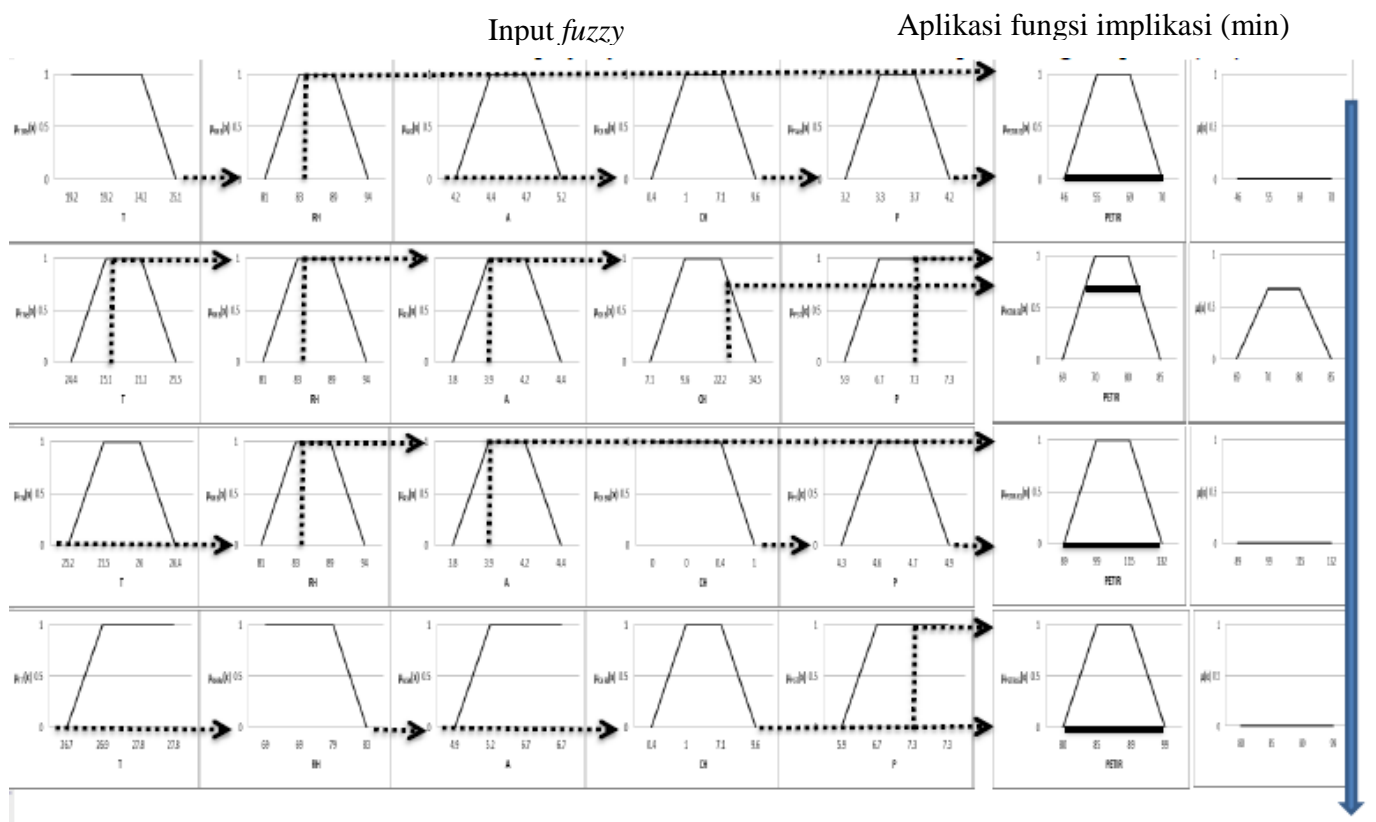

Gambar 7 Proses agregasi semua aturan model frekuensi petir

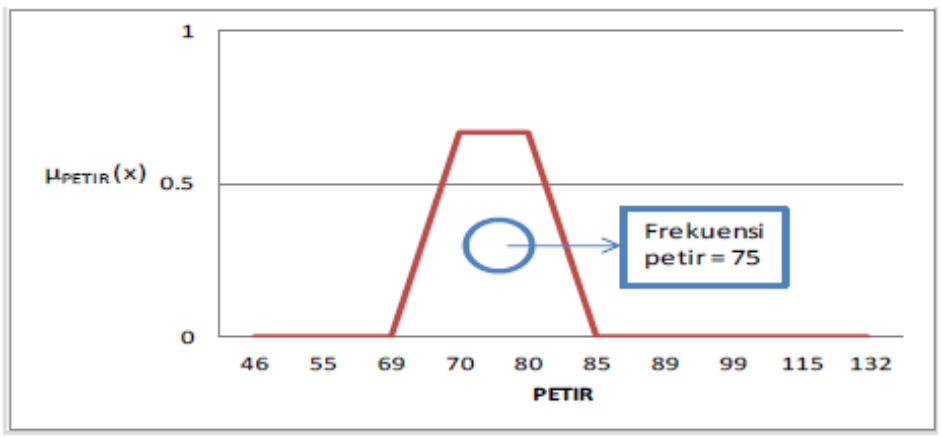

Gambar 8 Hasil Perhitungan dari Agregasi Semua Aturan Model Frekuensi Petir

\section{UKURAN KESALAHAN MENGGUNAKAN MAPE}

Nilai MAPE berdasarkan data dan model yang dihasilkan adalah sebesar 17.2\%. Nilai MAPE tersebut dapat mengindikasi seberapa besar kesalahan dalam menyusun model frekuensi petir. Ukuran kesalahan sebesar $17.2 \%$ merupakan dugaan model yang dinyatakan dalam bentuk persentase absolut kesalahan. Nilai keakuratan tersebut belum dapat dikatakan baik atau buruk dari suatu model karena belum ada acuan dari penelitian sebelumnya mengenai model frekuensi petir. 


\section{SIMPULAN}

Berdasarkan hasil penelitian, dapat disimpulkan bahwa logika fuzzy dapat digunakan dalam membuat model frekuensi petir dengan variabel input suhu udara ratarata, penguapan, kelembaban udara, kecepatan angin, penguapan, dan curah hujan. Metode yang digunakan adalah fuzzy Mamdani (metode min-max) dan pada penegasan (deffuzifikasi) menggunakan metode centroid. Pemodelan frekuensi petir ini memungkinkan untuk memprediksi frekuensi petir ketika lightning counter mengalami gangguan. MAPE yang dihasilkan adalah sebesar $17.2 \%$ berdasarkan data dan model frekuensi petir pada tahun 2012. Pemodelan frekuensi petir ini akan lebih baik jika dapat menggunakan data lebih dari satu tahun agar dapat memperkecil ukuran kesalahan.

\section{DAFTAR PUSTAKA}

[1] Akbar A. 2012. Pruning pada Fuzzy Decision Tree dalam Klasifikasi Data Iklim dan Titik Api di Daerah Tjilik Riwut, Palangkaraya, Kalimantan Selatan [skripsi]. Bogor (ID): Institut Pertanian Bogor.

[2] Asdak C. 1995. Hidrologi dan Pengelolaan Daerah Aliran Sungai. Yogyakarta (ID): Gajah Muda University Press.

[3] Byers JR. 1997. Element of Cloud Physics. Chicago (US): The University of Chicago Press.

[4] Susilo Frans SJ. 2003. Himpunan dan Logika Kabur Serta Aplikasinya. Yogyakarta (ID): Graha Ilmu Yogyakarta.

[5] Hidayat S. 2008. Ketika Petir Menyambar Tower BTS [internet]. [diacu 2013 November 10]. Tersedia pada: http://www.wordpress.com/2008/04/10/html.

[6] Husni M. 2002. Mengenal Bahaya Petir. Jurnal Meteorologi dan Geofisika Vol 3 No. 4 Oktober Desember 2002. Jakarta (ID).

[7] Kusumadewi S, Purnomo H. 2010. Analisis Logika Fuzzy untuk Mendukung Keputusan. Yogyakarta (ID): Graha Ilmu.

[8] Makridakis S, Wheelwright SC, McGee VE. 1995. Metode dan Aplikasi Peramalan. Adriyanto US dan Basith A, penerjemah. Jakarta (ID): Erlangga.

[9] Marimin. 2002. Teori dan Aplikasi Sistem Pakar dalam Teknologi Manajerial. Bogor (ID): IPB Press - Pascasarjana IPB.

[10] Maryati. 2013. Periset Jepang Teliti Petir di Bogor. Antara News. D0-18.

[11] Septiadi D. 2012. Karakteristik Petir Terkait Curah Hujan Lebat di Wilayah Bandung, Jawa Barat [Skripsi]. Bogor (ID): Institut Pertanian Bogor.

[12] Suharsono H. 1982. Beberapa Aspek Iklim Bogor [Skripsi]. Bogor (ID): Jurusan Agrometeorologi Departemen Ilmu Pengetahuan Alam Fakultas Pertanian Institut Pertanian Bogor.

[13] Tjasyono Bayong HK. 2004. Klimatologi Edisi Ke-2. Bandung (ID): ITB Press.

[14] Zadeh L. 1996. Fuzzy Logic: Computing with words, IEEE Transactions on Fuzzy System. 